Available online at GSC Online Press Directory

GSC Biological and Pharmaceutical Sciences

e-ISSN: 2581-3250, CODEN (USA): GBPSC2

Journal homepage: https://www.gsconlinepress.com/journals/gscbps

(RESEARCH ARTICLE)

\title{
Diversity and abundance of insects in cotton crop land of Punjab, Pakistan
}

\author{
Raza Taqi ${ }^{1,}{ }^{*}$, Rehman Talha ${ }^{1}$, Nawaz Ahmad ${ }^{1}$, Javed Muhammad Uamr ${ }^{1}$ and Ullah Sami ${ }^{2}$ \\ ${ }^{1}$ Department of Entomology, Faculty of Agriculture, University of Agriculture Faisalabad 38000, Punjab, Pakistan. \\ ${ }^{2}$ Department of Soil and Environmental Sciences, Faculty of agriculture, University of Agriculture Faisalabad 38000, \\ Punjab, Pakistan.
}

Publication history: Received on 06 November 2019; revised on 22 November 2019; accepted on 26 November 2019

Article DOI: https://doi.org/10.30574/gscbps.2019.9.2.0209

\begin{abstract}
Cotton crops have central role in Pakistan's economy. Cotton belongs to Kingdom plantae, Family Malvacea and genus Gossypium. Gossypium arboretum species of cotton is cultivated in Pakistan. Macro invertebrates are organisms that lack spine and large enough to seen with the naked eye. The present research is performed to check the diversity and abundance of different insects on cotton crop from two districts of province Punjab, Pakistan. Sampling was done from Multan and Faisalabad. The specimens were collected through the use of hand net bowl trap and sweep net. A total no 38 species, 9 orders and 25 families were identified. Specimens were identified by using taxonomic keys. Shannon Weiner diversity index was used to analyze the data. 38 species were identified from Multan belonging to 9 orders and 190 specimens whereas 34 species collected from Faisalabad belong to 9 order, 25 families and 300 specimens. The Shannon Weiner diversity index value of macro invertebrates on cotton crop of Multan was calculated as $\mathrm{H}^{\prime}=1.37 \%$, $\mathrm{E}=0.99 \%$ and of Faisalabad it was $\mathrm{H}^{\prime}=1.33 \%, \mathrm{E}=0.96 \%$.
\end{abstract}

Keywords: Cotton Crop; Multan; Faisalabad; Collection; Identification; No of species

\section{Introduction}

In topical's and sub topical's country a cultivated area of cotton is about $2.4 \%$ of the arid able land. Twenty million farmers are those which totally dependent on cotton production and many are those which included cotton into their rotation scheme (the sequence in which growing of diverse crops on the same ground to maintain soil nutrient and enlarge richness) is studied. Fifty percent of fiber exploitation of world is evolved from cotton. Use up of cotton fiber is increasing gradually and in 2010 shortage rate predicted was 15\% [1].

Insects of cotton which are belong to order Lepidoptera accessible in entire parts of the world. In Uganda approximately $80 \%$ crucial loss will be happening if bollworm complex were not prohibited. Normally these pests are excluded by the usage of cultural methods, use of resistant varieties, use of transgenic Bt cotton, and by use insecticides in a broad range to control these pests. Pest struggle against the insecticides and as a result Environmental issues occur [2][3][4]. Due to lack of effective pesticides and a reduced amount of new pesticides macro invertebrates increase large amount in cotton crops [5]. Cotton insect are categorized into chewing insect pests on the basis of feeding behavior e.g. spotted bollworms (Erias insulana), pink bollworm (Pectinphora gossypiella), and army bollworms (Spodoptera litura). Jassid (Amrascade vastans), thrip (Thrips tabacii), whitefly (Bemisia tabacii), mites (Tetranychus spp) aphid (Aphis gossypii) are sucking insects they nourish on bolls, leaves, buds and, flowers. Pest attract the morphological anatomical appearance of plant like okra leaf shape, color, spines on leaves, lignifications of cell walls, frego bract shape, hairs and evidence of waxes and strength of tissue etc. due to these features insects' prefer these host plants [6]. The Soil macro fauna is important in functioning of ecosystem as they change the physical properties of soil and through decomposition process improve the nutrient cycle [7].

\footnotetext{
${ }^{*}$ Corresponding author

E-mail address: razakungtaqi@gmail.com
} 
Malvacea is the family and Gossypium is genus of cotton plants. They contain 13 sets of chromosomes. The wild species of cotton occurred all around the world except in Europe. 35 species of cotton are present or dispersed in tropical and subtropical region. In Pakistan only four species are present. In Pakistan G. hirsutum L, G. herbaceum L, G.stocksii Mast and G. arboreum. G. hirsutum are present. Cotton is cultivated as summer crop in april and june at different regions of Pakistan [8].

Phytophagus arthropods are attacked on cotton crop (Gossypium hirsutum L.) and cause serious damage to cropland in the new world key pest of cotton is boll weevil Anthonomus grandis (Coleoptera: Curculionidae) [9]. In Brazil, this insect has spread throughout the cotton-producing regions which cause severe increase in the cost of production due to economic losses. The feeding behavior and ovipositon on cotton squares and bolls result in a lot of economic loss [10].

\section{Material and methods}

The materials which were used the collection of rats, electric grinder, cages, sieve, gloves, Chloroform, weight balance, cotton, stirrer, and beakers.

\subsection{Study Area}

In the region of central Punjab, Pakistan which is located between latitude $30^{\circ} 31.5^{\circ}$ north longitude $73^{\circ} 74^{\circ}$ toward the east, 184.4 meters above sea level with a highest standard temperature of $35^{\circ} \mathrm{C}$ throughout summer and least standard temperature of $-5{ }^{\circ} \mathrm{C}$ District Faisalabad and Multan are located. Basically, Punjab has three major seasons for cotton sowing and world's best cotton producer. Central Punjab is most developed part of province and a large area is used for cotton sowing. A no of areas of district Faisalabad and Multan were selected to collect the macro invertebrates and cotton was selected to check the abundance of insect pests with randomized area selection.

\subsection{Collection}

Insects were collected from different areas in such arrangement that by dividing the fields into blocks and then hotspot. A minimum area of 0.5 acre of respective field was designed for the collection of insects in each hotspot. Each crop was further designed to divide into 4 replicates. Bluish and yellowish bowl traps were placed in cross manner on ground for about 2 hours in a $2 \mathrm{~m}$ area of respective replicates. Time was noted continuously during the whole procedure of collection. The visible data was also recorded and was strengthened by use of hand net, bowl trap and sweep net. After two days two hotspots were studied and different specimens were collected continuously except when climate were not suitable for insect collection.

\subsection{Preservation}

Insects were collected from each hotspot and were placed in Styrofoam box in a proper manner and tagged.

\subsection{Identification}

The overall data was identified with the help of taxonomic keys and by comparing with internet sources and also by Entomological museum of Department of Agricultural Sciences University of Agriculture Faisalabad Pakistan.

\subsection{Statistical Analysis}

Data was analyzed statistically to determine species diversity, abundance and species richness/evenness with Shannon Weiner diversity index (Shannon, 1998). Diversity index was calculated by using Minitab Software for statistical analysis.

Diversity index calculated by using formula,

$$
\mathrm{H}^{\prime}=\mathrm{Nin}-\sum \operatorname{ninn} / \mathrm{N}
$$

The magnitude of

$$
\mathrm{E}=\mathrm{H}^{\prime} / \mathrm{In} \mathrm{S}
$$

The quality E termed as Evenness also refers as Homogeneity or relative diversity. 


\section{Results and discussion}

In this research collecting the diversity and abundance of different insect species on cotton crop in two major cotton growing areas of Pakistan. These two areas are Multan and Faisalabad.

Cotton insects in selected areas of Punjab are given in table 1 and 2. In some selected field of these districts 12 orders with 25 families and 490 insect's species present belonging to three classes.

Table 1 Diversity and abundance of insects in Faisalabad

\begin{tabular}{|c|c|c|c|c|}
\hline $\begin{array}{l}\text { Sr. } \\
\text { No. } \\
\end{array}$ & Order & Family & Species & In Faisalabad\% \\
\hline \multirow[t]{7}{*}{1} & Orthoptera & Acridae & Acrida spp & 3.66 \\
\hline & & & Acrida lugubris & 0.33 \\
\hline & & & Cyrtacanthacris ranacae & - \\
\hline & & & Triulia dimidata & 0.33 \\
\hline & & & Schistocera gregaria & $0.33 \%$ \\
\hline & & & Heteropternis respondens & $2.33 \%$ \\
\hline & & Tettigonidae & Neoconocepha lusensiger & $1 \%$ \\
\hline \multirow[t]{5}{*}{2} & Lepidoptera & Pyralidae & Cnaphalocrocis medinalis & $0.33 \%$ \\
\hline & & Tortricidae & Xenthotemna pallorana & - \\
\hline & & Hesperidae & Nastraither minia & $1.67 \%$ \\
\hline & & & Amblyscirtes oneus & - \\
\hline & & Choreutidae & Hemirophila diva & $16.67 \%$ \\
\hline \multirow[t]{2}{*}{3} & Gastropoda & Zonitidae & Hyalinia crystalline & - \\
\hline & & & Hyalinia pura & $0.67 \%$ \\
\hline \multirow[t]{4}{*}{4} & Odonata & Coenagrionidae & Coenagrion puella & $0.67 \%$ \\
\hline & & & Erynthrodi plexbrenice & $0.33 \%$ \\
\hline & & Lebilullidae & Orthemus ferrugenia & - \\
\hline & & & Crocothemis servilia & - \\
\hline \multirow[t]{8}{*}{5} & Hemiptera & Lygaeidae & Ischnodemus falicus & $0.67 \%$ \\
\hline & & & Lygaeuss exatilus & $3.67 \%$ \\
\hline & & & Lygaeusneo coryphus & $0.33 \%$ \\
\hline & & & Oxycarenus hyalenipenis & $33.33 \%$ \\
\hline & & Lophopidae & Pyrilla perpusella & $0.67 \%$ \\
\hline & & Reduviidae & Rhinocoris ventalis & - \\
\hline & & Pentatomidae & Podisus nigrispinus & $1.67 \%$ \\
\hline & & & Nazara viridula & $0.33 \%$ \\
\hline 6 & Neuroptera & Chrysopidae & Chrysoper lacarnia & $8.67 \%$ \\
\hline \multirow[t]{8}{*}{7} & Coleoptera & Scolytida & Hylurgopinusru fipes & $0.33 \%$ \\
\hline & & & Dandroctonus Valens & $0.67 \%$ \\
\hline & & Coccinellidae & Micraspes allardi & $0.67 \%$ \\
\hline & & & Coccinella larvae & $1.33 \%$ \\
\hline & & & Paederus fuscipes & $1.67 \%$ \\
\hline & & & Hippodamia convergens & $1 \%$ \\
\hline & & Curculionidae & Tanymecus palliates & $5 \%$ \\
\hline & & Dermistidae & Attagenus unicolor & $1 \%$ \\
\hline \multirow[t]{7}{*}{8} & Hymenoptera & Formacidae & Solenop sisinvicta & $2 \%$ \\
\hline & & Apidae & Apis mellifora & $1.67 \%$ \\
\hline & & Vespidae & & - \\
\hline & & Andrenidae & Andrena prima & - \\
\hline & & & Andrena wakella & $1 \%$ \\
\hline & & Dryinidae & Gontopus paraleptus & - \\
\hline & & Sphecidae & & $0.33 \%$ \\
\hline \multirow[t]{2}{*}{9} & Araneae & Oxyopidae & Oxyopes javanus & $2.33 \%$ \\
\hline & Total & & & 300 \\
\hline
\end{tabular}


Table 2 Diversity and abundance of insects in Multan

\begin{tabular}{|c|c|c|c|c|}
\hline Sr\# & Order & Family & Species & In Multan \% \\
\hline \multirow[t]{7}{*}{1} & Orthoptera & Acridae & Acrida spp & $4.2 \%$ \\
\hline & & & Acrida lugubris & $1.05 \%$ \\
\hline & & & Cyrtacanthacris ranacae & $0.53 \%$ \\
\hline & & & Triulia dimidata & $0.53 \%$ \\
\hline & & & Schistocera gregaria & $0.53 \%$ \\
\hline & & & Heteropternis respondens & 2.63 \\
\hline & & Tettigonidae & Neoconocepha lusensiger & 1.05 \\
\hline \multirow[t]{5}{*}{2} & Lepidoptera & Pyralidae & Cnaphalocrocis medinalis & $1.58 \%$ \\
\hline & & Tortricidae & Xenthotemna pallorana & 0.53 \\
\hline & & Hesperidae & Nastraither minia & 2.10 \\
\hline & & & Amblyscirtes oneus & 0.53 \\
\hline & & Choreutidae & Hemirophila diva & 14.73 \\
\hline \multirow[t]{2}{*}{3} & Gastropoda & Zonitidae & Hyalinia crystalline & $0.53 \%$ \\
\hline & & & Hyalinia pura & - \\
\hline \multirow[t]{4}{*}{4} & Odonata & Coenagrionidae & Coenagrion puella & 0.53 \\
\hline & & & Erynthrodi plexbrenice & - \\
\hline & & Lebilullidae & Orthemus ferrugenia & $0.53 \%$ \\
\hline & & & Crocothemis servilia & $1.58 \%$ \\
\hline \multirow[t]{8}{*}{5} & Hemiptera & Lygaeidae & Ischnodemus falicus & $0.53 \%$ \\
\hline & & & Lygaeuss exatilus & $3.68 \%$ \\
\hline & & & Lygaeusneo coryphus & $1.05 \%$ \\
\hline & & & Oxycarenus hyalenipenis & $22.63 \%$ \\
\hline & & Lophopidae & Pyrilla perpusella & - \\
\hline & & Reduviidae & Rhinocoris ventalis & $0.53 \%$ \\
\hline & & Pentatomidae & Podisus nigrispinus & $2.10 \%$ \\
\hline & & & Nazara viridula & - \\
\hline 6 & Neuroptera & Chrysopidae & Chrysoper lacarnia & $15.78 \%$ \\
\hline \multirow[t]{8}{*}{7} & Coleoptera & Scolytida & Hylurgopinusru fipes & 2.10 \\
\hline & & & Dandroctonus Valens & $0.58 \%$ \\
\hline & & Coccinellidae & Micraspes allardi & - \\
\hline & & & Coccinella larvae & 1.05 \\
\hline & & & Paederus fuscipes & $1.58 \%$ \\
\hline & & & Hippodamia convergens & $0.53 \%$ \\
\hline & & Curculionidae & Tanymecus palliates & $4.74 \%$ \\
\hline & & Dermistidae & Attagenus unicolor & - \\
\hline \multirow[t]{7}{*}{8} & Hymenoptera & Formacidae & Solenop sisinvicta & 2.10 \\
\hline & & Apidae & Apis mellifora & $1.57 \%$ \\
\hline & & Vespidae & & $1.05 \%$ \\
\hline & & Andrenidae & Andrena prima & $1.05 \%$ \\
\hline & & & Andrena wakella & $0.53 \%$ \\
\hline & & Dryinidae & Gontopus paraleptus & $0.53 \%$ \\
\hline & & Sphecidae & & $0.53 \%$ \\
\hline \multirow[t]{2}{*}{9} & Araneae & Oxyopidae & Oxyopes javanus & $2.63 \%$ \\
\hline & Total & & & 190 \\
\hline
\end{tabular}


Table 3 Relative abundance of insects in Multan and Faisalabad

\begin{tabular}{|c|c|c|c|c|c|c|}
\hline Sr\# & Order & Family & Species & Multan & Faisalabad & Total \\
\hline \multirow[t]{7}{*}{1} & Orthoptera & Acridae & Acrida spp & $8(4.21 \%)$ & $11(3.66 \%)$ & 19 \\
\hline & & & Acrida lugubris & $2(1.05 \%)$ & $1(0.33 \%)$ & 3 \\
\hline & & & Cyrtacanthacris ranacae & $1(0.52 \%)$ & - & 1 \\
\hline & & & Triulia dimidata & $1(0.52 \%)$ & $1(0.33 \%)$ & 2 \\
\hline & & & Schistocera gregaria & $1(0.52 \%)$ & $1(0.33 \%)$ & 2 \\
\hline & & & Heteropternis respondens & $5(2.63 \%)$ & $7(2.33 \%)$ & 12 \\
\hline & & Tettigonidae & Neoconocepha lusensiger & $2(1.05 \%)$ & $3(1 \%)$ & 5 \\
\hline \multirow[t]{5}{*}{2} & Lepidoptera & Pyralidae & Cnaphalocrocis medinalis & $3(1.57 \%)$ & $1(0.33 \%)$ & 4 \\
\hline & & Tortricidae & Xenthotemna pallorana & $1(0.52 \%)$ & - & 1 \\
\hline & & Hesperidae & Nastraither minia & $4(2.10 \%)$ & $5(1.66 \%)$ & 9 \\
\hline & & & Amblyscirtes oneus & $1(0.52 \%)$ & - & 1 \\
\hline & & Choreutidae & Hemirophila diva & $28(14.73 \%)$ & $50(16.66 \%)$ & 78 \\
\hline \multirow[t]{2}{*}{3} & Gastropoda & Zonitidae & Hyalinia crystalline & $1(0.52 \%)$ & - & 1 \\
\hline & & & Hyalinia pura & - & $2(0.66 \%)$ & 2 \\
\hline \multirow[t]{4}{*}{4} & Odonata & Coenagrionidae & Coenagrion puella & $1(0.52 \%)$ & $2(0.66 \%)$ & 3 \\
\hline & & & Erynthrodi plexbrenice & - & $1(0.33 \%)$ & 1 \\
\hline & & Lebilullidae & Orthemus ferrugenia & $1(0.52 \%)$ & - & 1 \\
\hline & & & Crocothemis servilia & $3(1.57 \%)$ & - & 3 \\
\hline \multirow[t]{8}{*}{5} & Hemiptera & Lygaeidae & Ischnodemus falicus & $1(0.52 \%)$ & $2(0.66 \%)$ & 3 \\
\hline & & & Lygaeuss exatilus & $7(3.68 \%)$ & $11(3.66 \%)$ & 18 \\
\hline & & & Lygaeusneo coryphus & $2(1.05 \%)$ & $1(0.33 \%)$ & 3 \\
\hline & & & Oxycarenus hyalenipenis & $43(22.63 \%)$ & $100(33.33 \%)$ & 143 \\
\hline & & Lophopidae & Pyrilla perpusella & - & $2(0.66 \%)$ & 2 \\
\hline & & Reduviidae & Rhinocoris ventalis & $1(0.52 \%)$ & - & 1 \\
\hline & & Pentatomidae & Podisus nigrispinus & $4(2.10 \%)$ & $5(1.66 \%)$ & 9 \\
\hline & & & Nazara viridula & - & $1(0.33 \%)$ & 1 \\
\hline 6 & Neuroptera & Chrysopidae & Chrysoper lacarnia & $30(15.78 \%)$ & $26(8.66 \%)$ & 56 \\
\hline \multirow[t]{8}{*}{7} & Coleoptera & Scolytida & Hylurgopinusrs fipes & $4(2.10 \%)$ & $1(0.33 \%)$ & 5 \\
\hline & & & Dandroctonus Valens & $1(0.52 \%)$ & $29(9.66 \%)$ & 3 \\
\hline & & Coccinellidae & Micraspes allardi & - & $2(0.66 \%)$ & 2 \\
\hline & & & Coccinella larvae & $2(1.05 \%)$ & $4(1.33 \%)$ & 6 \\
\hline & & & Paederus fuscipes & $3(1.57 \%)$ & $5(1.66 \%)$ & 8 \\
\hline & & & Hippodamia convergens & $1(0.52 \%)$ & $3(1 \%)$ & 4 \\
\hline & & Curculionidae & Tanymecus palliates & $9(4.73 \%)$ & $15(5 \%)$ & 24 \\
\hline & & Dermistidae & Attagenus unicolor & - & $3(1 \%)$ & 3 \\
\hline \multirow[t]{7}{*}{8} & Hymenoptera & Formacidae & Solenop sisinvicta & $4(2.10 \%)$ & $6(2 \%)$ & 10 \\
\hline & & Apidae & Apis mellifora & $3(1.57 \%)$ & $5(1.66 \%)$ & 8 \\
\hline & & Vespidae & & $2(1.05 \%)$ & 0 & 2 \\
\hline & & Andrenidae & Andrena prima & $2(1.05 \%)$ & 0 & 2 \\
\hline & & & Andrena wakella & $1(0.52 \%)$ & $3(1 \%)$ & 4 \\
\hline & & Dryinidae & Gontopus paraleptus & $1(0.52 \%)$ & - & 1 \\
\hline & & Sphecidae & & $1(0.52 \%)$ & $1(0.33 \%)$ & 2 \\
\hline \multirow[t]{2}{*}{9} & Araneae & Oxyopidae & Oxyopes javanus & $5(2.63 \%)$ & $7(2.33 \%)$ & 12 \\
\hline & Total & & & 190 & 300 & G.T $=490$ \\
\hline
\end{tabular}


Species collected from Order Orthoptera, Lepidoptera, Gastropoda, Odonata, Hemiptera, Neuroptera, Coleoptera, Hymenoptera and Araneae. In Orthoptera insects belonging to two major families Acridae (Species: Acridaspp, Acrida lugubris, Cyrtacanthcris ranacae, Triulia midata, Schistocera gregaria,) and Tettigonidae family with specimen belong to species Neoconocepha lusensiger. In Lepidoptera family Pyralidae (Cnaphalocrocis medinales),Torticidae (Xenthotemna pallorana), Hespidae(Nastraitherminia, Amblyscirtesoneus),Choreutidae (Hemirophila diva). In Gastropoda Family Zontidae (Hylina crystalline and Hylina pura). In odonata family Coenagrionidae (Coenagrion puella), and Lebilullidae (Erynthrodi plexbrenice, Orthemus ferrugenia,Crocothemis servilia). In order hemiptera family lygaeidae (Ischnodemus falicus,Lygaeuss falicus, Lygaeuss exantilus,Oxycarenus hyalenipenis) ,Lophopidae (Pyrilla perpusella),Reduviidae(Rhinocoris ventalis),Pentatomidae(Podisusnigris pinus, Nazara viridula).

In order Neuroptera family Chrysopidae (Chrysoper lacarnia) .In order Coleoptera families Scolytida (Hylurgopinusru fipes, Dandroctonus valens) and Coccinellidae (Micraspesallardi, Coccinella larvae, Paederus fuscipes, Hippodamia convergens), Curculionidae (Tanymecus palliates, Paederus fuscipes, Hippodamia convergens) and Dermistidae (Attagenus unicolor). In order Hymenoptera family Formacidae(Solenopsis invicta), Apidae(Apis mellifora), Vespidae, Andrenidae(Andrena prima, Andrena wakella), Dryinidae (Gontopus paraleptus) and Sphecidae.In order Araneae Family Oxyopidae (Oxyopes javanus)are included.

Order hemiptera with 177 species is more abundant among all orders, second is Lepidoptera with 93 species third is Neuroptera with 57 species order gastropoda with 1 family and 3 insect species and dictyoptera with 1 family and single insect species are least abundant among all others .

2 Families Coenagrionidae, lebilullidae which belong to order odonata, 2 families Acridae and Tettigonidae of Orthoptera, 4 Families lygaeidae, lophopidae, Reduviidae and Pentatomidae of Hemiptera,4 Families Scolytida, Coccinellidae, Curculionidae and Dermistidae of Coleoptera, 4 Families Pyralidae, Torticidae, Hesperidae and Choreutidae of Lepidoptera, 6 Families Formacidae, Apidae, Vespidae, Andrenidae, Dryinidae and Sphecidae of Hymenoptera, 1 Family Zonitidae which belong to order Gastropoda, collected by sampling from class insect.

Relative abundance of different insects is shown in Faisalabad (table 1). Order Hemiptera with relative abundance of 10.34\%, with 58 specimens, belonged to 4 families and 6 species. Second order Lepidoptera with 4 families with relative abundance 10.8\%, 5 species and 37 specimens. Order Orthopotera with relative abundance $10 \%$ : with 2 families 7 species and 20 specimens. The Order Coleoptera having 4 families with relative abundance of $20 \%$ and 6 species with 20 specimens. Order Hymenoptera with 6 families of 7 species with relative abundance of $42.85 \%$ in Multan.

Table 4 Shannon wiener diversity index

\begin{tabular}{llll}
\hline District & $\mathbf{N}$ & $\mathbf{H}$ & $\mathbf{E}$ \\
& & Shannon diversity & Evenness \\
\hline Multan & 190 & 1.37 & 0.99 \\
Faisalabad & 300 & 1.33 & 0.96 \\
\hline
\end{tabular}


Raza et al. / GSC Biological and Pharmaceutical Sciences 2019, 09(02), 117-125

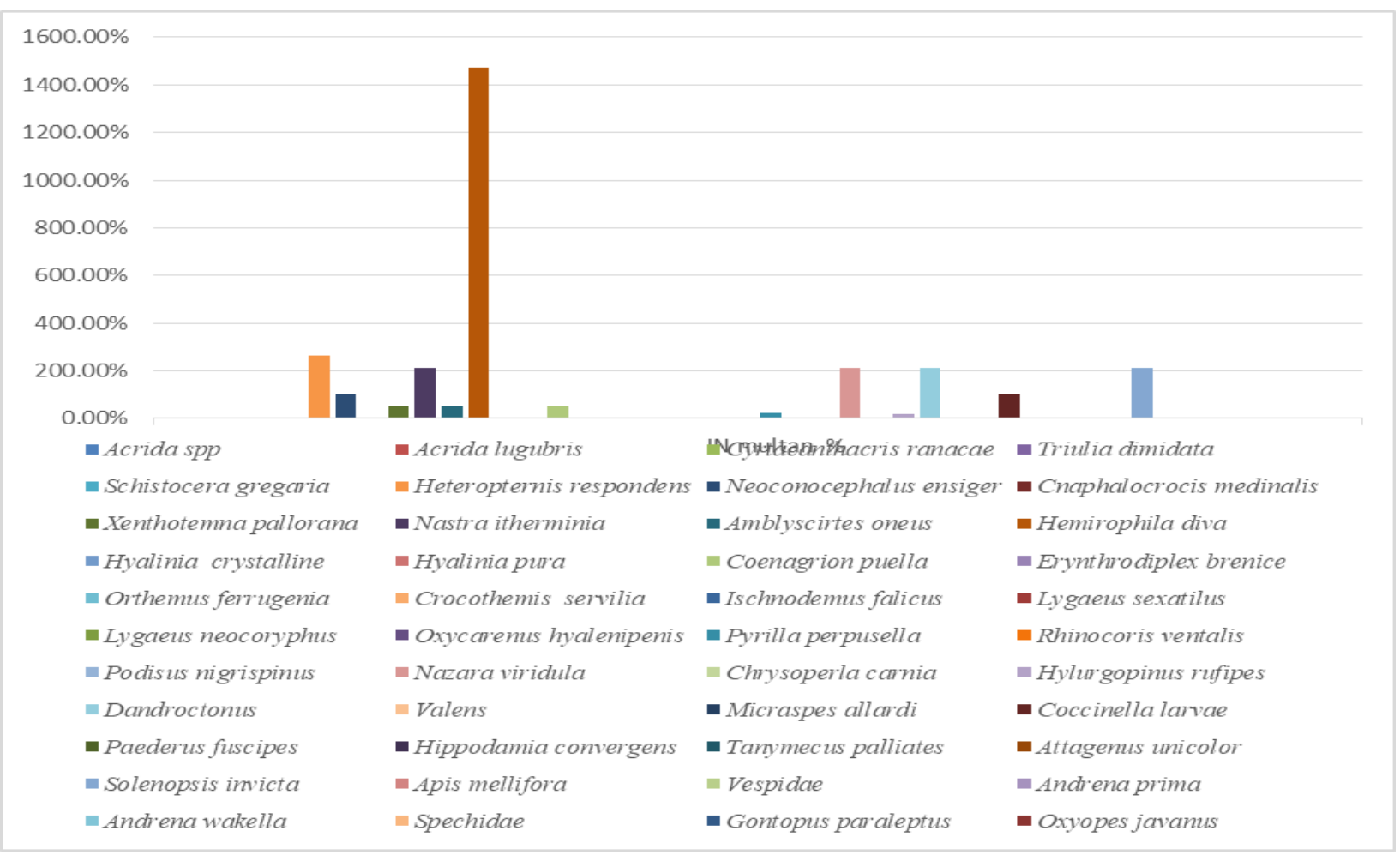

Figure 1 Showing relative abundance $\%$ of insects in cotton

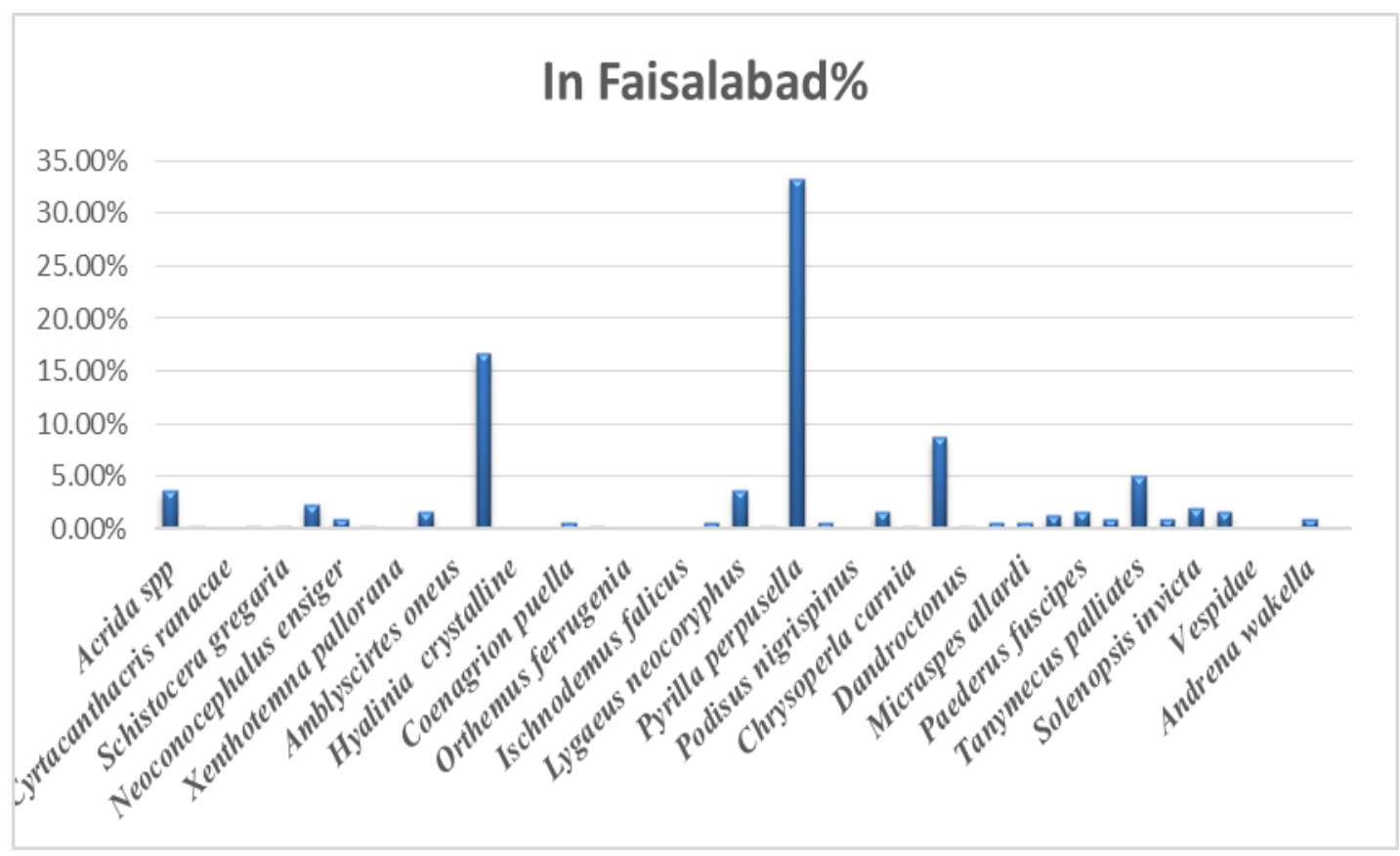

Figure 2 Showing relative diversity and abundance in Faisalabad

Cotton has no doubt a pivotal position in Pakistan `s agro based economy and important nonfood cash crop of a Pakistan. The surplus cotton is exported to provide a raw material in textile industries. The present production of cotton is lower than the targeted production due to insect pest with considerably damage the quality and reduced the yield of cotton [11]. The cotton plants belong to the genus Gossypium of the dicot family malvacea. The distribution of cotton species is worldwide and wild species are found in all the continents except Europe. In different countries cotton sown in April to June and in September picking were start and finished in January. In Pakistan the total area for cotton growing is 
3054.3 thousand hector in 2009 - 2010 with $649 \mathrm{~kg} / \mathrm{ha}$ is an usual production. $425 \mathrm{~kg} / \mathrm{ha}$ area were selected from Khyber Pakhtunkhwa for growing cotton crop and yield is maximum 0.2 ha [12]. Cotton productions have been static due to numerous reasons. And reason of this is heavy rain when sowing occur or high temperature. The most important factor is responsible for dropping quality of cotton is due to various insect pests [13]. Approximately 1326 type of insects had reported their attack on cotton in the whole world whereas regarding 93 insects or mites pest have been reported to attack cotton crop). In some selected fields as Multan and Faisalabad districts 12 orders with 25 families and 490 insect's species are present. In Faisalabad and Multan the highly abundant order is Hemiptera belonging to 4 families and 6 species, second is order Lepidoptera with 4 families and 5 species and then Order Orthopotera with 2 families and belonging to 7 species. Hemirophila diva with relative abundance of $16.67 \%$ and Oxycarenus hyalenipenis with $22.63 \%$ is most abundant in Faisalabad and Multan respectively.

\section{Conclusion}

The present view report conducted to estimate abundance and diversity of insects of different region of Punjab as Multan and Faisalabad. In this respect data is taken from different region of Punjab. Total specimens 490 belong to 9 Order, 25 families and 44 species are present in these regions.38 species are collected from Multan belong to 9 order and 190 specimens.34 species collected from Faisalabad belong to 9 order and 25 families and 300 specimens present in Faisalabad. The data analyzed by using Shannon Diversity index. The Shannon diversity of Multan is $\mathrm{H}^{\prime}=1.37 \%$, $\mathrm{E}=0.99 \%$ and from Faisalabad $\mathrm{H}^{\prime}=1.33 \%, \mathrm{E}=0.96 \%$.

\section{Compliance with ethical standards}

\section{Disclosure of conflict of interest}

All authors contributed equally and declare no conflict of interest exit among them.

\section{References}

[1] Nyakatawa EZ, Reddy KC and Lemunyon JL. (2001). Predicting soil erosion in conservation tillage cotton production systems using the revised universal soil loss equation (RUSLE). Soil and Tillage Research, 57(4), 21324.

[2] Meyer LA and MacDonald SA. (2001). Cotton Background and issues for farm legislation. USDA, Economic Research Service; Jul.

[3] Eveleens KG. (1983). Cotton-insect control in the Sudan Gezira: analysis of a crisis. Crop Protection, 2(57), 273-287.

[4] Jason C, Clay JW. (1982). World Agriculture and the Environment: a commodity-by-commodity guide to impacts and practices.

[5] Birner R, Davis K, Pender J, Nkonya E, Anandajayasekeram P, Ekboir J, Mbabu A, Spielman DJ, Horna D, Benin S and Cohen M. (2009). From best practice to best fit: a framework for designing and analyzing pluralistic agricultural advisory services worldwide. Journal of agricultural education and extension, 15(4), 341-55.

[6] Azmir J, Zaidul IS, Rahman MM, Sharif KM, Mohamed A, Sahena F, Jahurul MH, Ghafoor K, Norulaini NA, Omar AK. (2013). Techniques for extraction of bioactive compounds from plant materials: a review. Journal of Food Engineering, 117(4), 426-36.

[7] Nimon W and Beghin J. (1999). Are eco-labels valuable? Evidence from the apparel industry. American Journal of Agricultural Economics, 81(4), 801-11.

[8] Scheffer DM. (2001). A sustainable Vision on the Cotton Industry after 2005. Toespraak, gehouden tijdens de jaarvergadering van Eurocoton, 6, 30-34.

[9] Pilcher CD, Rice ME and Obrycki JJ. (2005). Impact of transgenic Bacillus thuringiensis corn and crop phenology on five nontarget arthropods. Environmental Entomology, 34(5), 1302-16.

[10] Silva CD and Ramalho FD. (2013). Kaolin spraying protects cotton plants against damages by boll weevil Anthonomus grandis Boheman (Coleoptera: Curculionidae). Journal of Pest Science, 86(3), 563-9.

[11] Ashfaq M and Young SY. (1999). Effect of transgenic Bt-cotton on larval mortality and development of beet armyworm, Spodoptera exigua (Lepidoptera: Noctuidae). InProceedings. 
[12] MINFAL. (2008). Agric. Statistics of Pakistan; Cash crops. Govt. of Pakistan, Ministry of Food, Agric. \& Livest. (Econ. Wing), Islamabad, 29-30.

[13] Kaplan I and Eubanks MD. (2002). Disruption of cotton aphid (Homoptera: Aphididae)—natural enemy dynamics by red imported fire ants (Hymenoptera: Formicidae). Environmental entomology, 31(6), 1175-83.

\section{How to cite this article}

Raza T, Rehman T, Nawaz A, Javed MU and Ullah S. (2019). Diversity and abundance of insects in cotton crop land of Punjab, Pakistan. GSC Biological and Pharmaceutical Sciences, 9(2), 117-125. 